\title{
Aquaporins in GtoPdb v.2021.3
}

\author{
Roslyn M. Bill ${ }^{1}$, Alex C. Conner ${ }^{2}$, Philip Kitchen ${ }^{1}$ and Mootaz Salman ${ }^{3}$ \\ 1. Aston University, UK \\ 2. University of Birmingham, UK \\ 3. Harvard Medical School, USA
}

\begin{abstract}
Aquaporins and aquaglyceroporins are membrane channels that allow the permeation of water and certain other small solutes across the cell membrane, or in the case of AQP6, AQP11 and AQP12A, intracellular membranes, such as vesicles and the endoplasmic reticulum membrane [16]. Since the isolation and cloning of the first aquaporin (AQP1) [20], 12 additional mammalian members of the family have been identified, although little is known about the functional properties of one of these (AQP12A; Q8IXF9) and it is thus not tabulated. The other 12 aquaporins can be broadly divided into three families: orthodox aquaporins (AQP0,-1,-2,-4,-5, -6 and -8) permeable mainly to water, but for some additional solutes [4]; aquaglyceroporins (AQP3,-7 -9 and -10), additionally permeable to glycerol and for some isoforms urea [14], and superaquaporins (AQP11 and 12) located within cells [12]. Some aquaporins also conduct ammonia and/or $\mathrm{H}_{2} \mathrm{O}_{2}$ giving rise to the terms 'ammoniaporins' ('aquaammoniaporins') and 'peroxiporins', respectively. Aquaporins are impermeable to protons and other inorganic and organic cations, with the possible exception of AQP1, although this is controversial [14]. One or more members of this family of proteins have been found to be expressed in almost all tissues of the body [reviewed in Yang (2017) [26]]. AQPs are involved in numerous processes that include systemic water homeostasis, adipocyte metabolism, brain oedema, cell migration and fluid secretion by epithelia. Loss of function mutations of some human AQPs, or their disruption by autoantibodies further underscore their importance [reviewed by Verkman et al. (2014) [23], Kitchen et al. (2105) [14]].

Functional AQPs exist as homotetramers that are the water conducting units wherein individual AQP subunits (each a protomer) have six TM helices and two half helices that constitute a seventh 'pseudotransmembrane domain' that surrounds a narrow water conducting channel [16]. In addition to the four pores contributed by the protomers, an additional hydrophobic pore exists within the center of the complex [16] that may mediate the transport through AQP1. Although numerous small molecule inhibitors of aquaporins, particularly APQ1, have been reported primarily from Xenopus oocyte swelling assays, the activity of most has subsequently been disputed upon retesting using assays of water transport that are less prone to various artifacts [5] and they are therefore excluded from the tables [see Tradtrantip et al. (2017) [22] for a review].
\end{abstract}

\section{Contents}

This is a citation summary for Aquaporins in the Guide to Pharmacology database (GtoPdb). It exists purely as an adjunct to the database to facilitate the recognition of citations to and from the database by citation analyzers. Readers will almost certainly want to visit the relevant sections of the database which are given here under database links.

GtoPdb is an expert-driven guide to pharmacological targets and the substances that act on them. GtoPdb is a reference work which is most usefully represented as an on-line database. As in any publication this work should be appropriately cited, and the papers it cites should also be recognized. This document provides a citation for the relevant parts of the database, and also provides a reference list for the research cited by those parts. For further details see [2].

Please note that the database version for the citations given in GtoPdb are to the most recent preceding version in which the family or its subfamilies and targets were substantially changed. The links below are to the current version. If you need to consult the cited version, rather than the most recent version, please contact the GtoPdb curators. 


\section{Database links}

Aquaporins

https://www.guidetopharmacology.org/GRAC/FamilyDisplayForward?familyId=119

Channels and Subunits

AQP0

https://www.guidetopharmacology.org/GRAC/ObjectDisplayForward?objectId=687

AQP1

https://www.guidetopharmacology.org/GRAC/ObjectDisplayForward?objectId=688

AQP2

https://www.guidetopharmacology.org/GRAC/ObjectDisplayForward?objectId=689

AQP3

https://www.guidetopharmacology.org/GRAC/ObjectDisplayForward?objectId=690

AQP4

https://www.guidetopharmacology.org/GRAC/ObjectDisplayForward?objectId=691

AQP5

https://www.guidetopharmacology.org/GRAC/ObjectDisplayForward?objectId=692

AQP6

https://www.guidetopharmacology.org/GRAC/ObjectDisplayForward?objectId=693

AQP7

https://www.guidetopharmacology.org/GRAC/ObjectDisplayForward?objectId=694

AQP8

https://www.guidetopharmacology.org/GRAC/ObjectDisplayForward?objectId=695

AQP9

https://www.guidetopharmacology.org/GRAC/ObjectDisplayForward?objectId=696

AQP10

https://www.guidetopharmacology.org/GRAC/ObjectDisplayForward?objectId=697 AQP11

https://www.guidetopharmacology.org/GRAC/ObjectDisplayForward?objectId=3062

\section{References}

1. Bienert GP and Chaumont F. (2014) Aquaporin-facilitated transmembrane diffusion of hydrogen peroxide. Biochim Biophys Acta 1840: 1596-604 [PMID:24060746]

2. Buneman P, Christie G, Davies JA, Dimitrellou R, Harding SD, Pawson AJ, Sharman JL and Wu Y. (2020) Why data citation isn't working, and what to do about it Database $\mathbf{2 0 2 0}$

[PMID:32367113]

3. Chow PH, Kourghi M, Pei JV, Nourmohammadi S and Yool AJ. (2020) 5-Hydroxymethyl-Furfural and Structurally Related Compounds Block the Ion Conductance in Human Aquaporin-1 Channels and Slow Cancer Cell Migration and Invasion. Mol Pharmacol 98: 38-48 [PMID:32434851]

4. Day RE, Kitchen P, Owen DS, Bland C, Marshall L, Conner AC, Bill RM and Conner MT. (2014) Human aquaporins: regulators of transcellular water flow. Biochim Biophys Acta 1840: 1492506 [PMID:24090884]

5. Esteva-Font C, Jin BJ, Lee S, Phuan PW, Anderson MO and Verkman AS. (2016) Experimental Evaluation of Proposed Small-Molecule Inhibitors of Water Channel Aquaporin-1. Mol Pharmacol 89: 686-93 [PMID:26993802]

6. Garneau AP, Carpentier GA, Marcoux AA, Frenette-Cotton R, Simard CF, Rémus-Borel W, Caron L, Jacob-Wagner M, Noël M and Powell JJ et al.. (2015) Aquaporins Mediate Silicon Transport in Humans. PLoS ONE 10: e0136149 [PMID:26313002]

7. Geyer RR, Musa-Aziz R, Qin X and Boron WF. (2013) Relative CO(2)/NH(3) selectivities of mammalian aquaporins 0-9. Am J Physiol, Cell Physiol 304: C985-94 [PMID:23485707]

8. Holm LM, Jahn TP, Møller AL, Schjoerring JK, Ferri D, Klaerke DA and Zeuthen T. (2005) NH3 and NH4+ permeability in aquaporin-expressing Xenopus oocytes. Pflugers Arch 450: 415-28 [PMID:15988592]

9. Holm LM, Klaerke DA and Zeuthen T. (2004) Aquaporin 6 is permeable to glycerol and urea. Pflugers Arch 448: 181-6 [PMID:14985982]

10. Ishibashi K, Kuwahara M, Gu Y, Kageyama Y, Tohsaka A, Suzuki F, Marumo F and Sasaki S. (1997) Cloning and functional expression of a new water channel abundantly expressed in the testis permeable to water, glycerol, and urea. J Biol Chem 272: 20782-6 [PMID:9252401]

11. Ishibashi K, Morinaga T, Kuwahara M, Sasaki S and Imai M. (2002) Cloning and identification of a new member of water channel (AQP10) as an aquaglyceroporin. Biochim Biophys Acta 1576: 335-40 [PMID:12084581]

12. Ishibashi K, Tanaka Y and Morishita Y. (2014) The role of mammalian superaquaporins inside the cell. Biochim Biophys Acta 1840: 1507-12 [PMID:24189537] 
13. Kaldenhoff R, Kai L and Uehlein N. (2014) Aquaporins and membrane diffusion of CO2 in living organisms. Biochim Biophys Acta 1840: 1592-5 [PMID:24141139]

14. Kitchen P, Day RE, Salman MM, Conner MT, Bill RM and Conner AC. (2015) Beyond water homeostasis: Diverse functional roles of mammalian aquaporins. Biochim Biophys Acta 1850: 2410-21 [PMID:26365508]

15. Kitchen P, Salman MM, Halsey AM, Clarke-Bland C, MacDonald JA, Ishida H, Vogel HJ, Almutiri S, Logan A and Kreida S et al.. (2020) Targeting Aquaporin-4 Subcellular Localization to Treat Central Nervous System Edema. Cell 181: 784-799.e19 [PMID:32413299]

16. Kreida S and Törnroth-Horsefield S. (2015) Structural insights into aquaporin selectivity and regulation. Curr Opin Struct Biol 33: 126-34 [PMID:26342685]

17. Ma T, Yang B and Verkman AS. (1997) Cloning of a novel water and urea-permeable aquaporin from mouse expressed strongly in colon, placenta, liver, and heart. Biochem Biophys Res Commun 240: 324-8 [PMID:9388476]

18. Madeira A, Fernández-Veledo S, Camps M, Zorzano A, Moura TF, Ceperuelo-Mallafré V, Vendrell J and Soveral G. (2014) Human aquaporin-11 is a water and glycerol channel and localizes in the vicinity of lipid droplets in human adipocytes. Obesity (Silver Spring) 22: 2010-7 [PMID:24845055]

19. Martins AP, Marrone A, Ciancetta A, Galán Cobo A, Echevarría M, Moura TF, Re N, Casini A and Soveral G. (2012) Targeting aquaporin function: potent inhibition of aquaglyceroporin-3 by a gold-based compound. PLoS ONE 7: e37435 [PMID:22624030]

20. Preston GM, Carroll TP, Guggino WB and Agre P. (1992) Appearance of water channels in Xenopus oocytes expressing red cell CHIP28 protein. Science 256: 385-7 [PMID:1373524]

21. Rambow J, Wu B, Rönfeldt D and Beitz E. (2014) Aquaporins with anion/monocarboxylate permeability: mechanisms, relevance for pathogen-host interactions. Front Pharmacol 5: 199 [PMID:25225485]

22. Tradtrantip L, Jin BJ, Yao X, Anderson MO and Verkman AS. (2017) Aquaporin-Targeted Therapeutics: State-of-the-Field. Adv Exp Med Biol 969: 239-250 [PMID:28258578]

23. Verkman AS, Anderson MO and Papadopoulos MC. (2014) Aquaporins: important but elusive drug targets. Nat Rev Drug Discov 13: 259-77 [PMID:24625825]

24. Wang Y and Tajkhorshid E. (2010) Nitric oxide conduction by the brain aquaporin AQP4. Proteins 78: 661-70 [PMID:19842162]

25. Watanabe S, Moniaga CS, Nielsen S and Hara-Chikuma M. (2016) Aquaporin-9 facilitates membrane transport of hydrogen peroxide in mammalian cells. Biochem Biophys Res Commun 471: 191-7 [PMID:26837049]

26. Yang B. (2017) Aquaporins In Advances in Experimental Medicine and Biology Edited by Yang B: Springer: 1-276 [ISBN: 9789402410570]

27. Yang B and Verkman AS. (1997) Water and glycerol permeabilities of aquaporins 1-5 and MIP determined quantitatively by expression of epitope-tagged constructs in Xenopus oocytes. J Biol Chem 272: 16140-6 [PMID:9195910] 